\title{
Pemanfaatan Media Power Point Untuk Meningkatkan Minat Belajar Bahasa Inggris Siswa Kelas VIII Sekolah Menengah Pertama Negeri 21 Kerinci
}

\author{
Jeni Tri Alida \\ Pascasarjana Universitas Jambi, Indonesia
}

Abstract: This research employs a class action of 2 cycles in grade VIII SMP Negeri 21 Kerinci with a total of 22 students. The data is collected using student interest questionnaires, observation sheets and interviews. The results found that there was an increase in interest in learning English from SMP Negeri 21 Kerinci students by utilizing power point media. The increase can be seen from the average result of student interest in pre cycles being at 22.8, in cycle I increasing to 27, 23, until cycle II increased to 35.11. To sum up, the media power point can increase the interest of learning English students of the State Junior High School 21 Kerinci after achieving the indicator of success that wants to be achieved that is in cycle II.

\section{Keyword: powerpoint media, learning interest, English language}

\section{Pendahuluan}

Bahasa merupakan alat yang paling signifikan didalam komunikasi. Komunikasi bisa dilakukan dengan berbicara, menulis dan lain sebagainya, melalui bahasa manusia mengungkapkan perasaan, ide-ide, dan pikirin kepada seseorang secara langsung, dengan selembar kertas atau dengan gerakan tubuh. Bahasa sangat penting untuk semua orang didunia karena dengan bahasa mereka mampu menjalin hubungan dengan orang lain yang berasal dari latarbelakang bahasa yang berbeda. Misalnya bahasa Inggris sebagai salah satu bahasa internasional yang digunakan sebagai alat komunikasi dalam forum-forum internasional. Oleh karena itu bahasa Inggris menjadi mata pelajaran yang sangat penting yang harus diajarkan sejak dini sampai dengan perguruan tinggi seperti SD, SMP, SMA dan Universitas.

Salah satu tujuan pembelajaran bahasa Inggris di SMP adalah mengembangkan kemampuan membaca dalam bahasa inggris. Reading Skill, merupakan salah satu kemampuan berbahasa yang penting untuk di kuasai oleh siswa sama seperti listening skill, speaking skill, ataupun writing skill. Hal ini dikarenakan reading skill (kemampuan membaca) merupakan basic tool yang paling penting dalam pembelajaran dan kehidupan sehari-hari. Pentingnya kemampuan membaca (reading skill) ini dikarenakan bahwa dengan membaca banyak ilmu pengetahuan yang akan di serap dan di dapatkan siswa. 


\section{Jeni Tri Alida}

Reading (membaca) bukanlah suatu proses yang sederhana, sebagai pembaca siswa di tuntut untuk bisa mengerti dan mendapatkan informasi dari sebuah text atau tulisan, sehingga dapat diartikan bahwa reading bukanlah suatu proses yang sederhana namun merupakan suatu proses yang kompleks yang melibatkan mata dan pikiran dalam menangkap informasi.

Berdasarkan silabus pendidikan bahasa Inggris di sekolah menengah pertama (SMP)Negeri 21 Kerinci di ketahui bahwa siswa telah mempelajari materi bahasa Inggris reading skill tentang beberapa jenis reading text, seperti descriptive text, narrative text, recount text dan seterusnya. Idealnya, siswa harusnya mampu dan mengerti tentang bacaan (teks) yang telah di pelajari tersebut. Namun pada kenyataannya siswa masih mengalami kesulitan dalam menganalisis bacaan dan mendapatkan informasi dari bacaan-bacaan tersebut. Hal ini di lihat dari rendahnya hasil belajar siswa pada materi reading dalam pembelajaran bahasa Inggris pada saat evaluasi pembelajaran. Dari jumlah total siswa dalam kelas tersebut, Hanya ada beberapa siswa saja yang memperoleh nilai di atas kriteria ketuntasan minimal yang telah ditetapkan, sedangkan sebagian besar siswa lainnya mendapatkan nilai di bawah standar ketuntasan minimal.

Rendahnya hasil belajar siswa di sebabkan oleh beberapa faktor yang dapat mempengaruhi proses dan hasi belajar di sekolah, yang diantaranya adalah faktor internal dan factor eksternal siswa. Faktor internal meliputi faktor dalam diri siswa seperti: kemampuan siswa, bakat, minat, perhatian, motivasi, sikap, cara belajar, dan lain-lain. Sedangkan faktor eksternal meliputi faktor dari luar siswa seperti kemampuan guru, dalam kelas, media pembelajaran yang digunakan, lingkungan sekolah, dan lain-lain.

Berdasarkan pemantauan yang dilakukan oleh peneliti pada saat proses pembelajaran Bahasa Inggris, disimpulkan bahwa rendahnya penguasaan siswa terhadap materi pelajaran bahasa Inggris disebabkan oleh rendahnya minat belajar siswa terhadap mata pelajaran bahasa Inggris. Hal ini ditunjukkan dengan kurangnya antusias siswa dalam menerima pelajaran, di sisi lain banyak juga siswa yang tidak memperhatikan dan bercanda pada saat mengikuti pembelajaran bahasa Inggris. Respon siswa dalam pembelajaran juga biasa-biasa saja, hanya ada beberapa siswa saja yang berani mengajukan pertanyaan dan mengemukakan pendapat.

Salah satu strategi pembelajaran yang bisa dilaksanakan adalah dengan memanfaatkan media pembelajaran yang inovatif dan menarik. Media merupakan sarana penyalur informasi di dalam proses belajar mengajar yang dapat membantu siswa lebih mudah dalam menyerap materi- 
materi tersebut. Salah satu media pembelajaran tersebut ialah dengan menggunakan Media Presentasi.

Media presentasi yang dapat di manfaatkan untuk meningkatkan minat belajar siswa khususnya pada mata Pelajaran Bahasa Inggris adalah media Power Point yang termasuk dalam media pembelajaran berbasis komputer dan memiliki aplikasi menampilkan slide berupa poinpoin materi yang menarik perhatian siswa saat belajar sehingga diharapkan munculnya minat belajar siswa khususnya pada mata Pelajaran Bahasa Inggris.

Berdasarkan latar belakang yang telah teruraikan di atas, maka peneliti merasa perlu untuk melakukan penelitian Pemanfaatan Media Power Point untuk Meningkatkan Minat Belajar Bahasa Inggris Siswa Kelas VIII SMP N 21 Kerinci.

\section{Landasan Teori}

\section{Pengertian Pemanfaatan}

Tujuan utama teknologi pembelajaran adalah untuk memecahkan masalah belajar atau memfasilitasi kegiatan pembelajaran. Menurut Warsita (2008: p.37) teknologi pendidikan adalah studi dan etika praktik dalam upaya memfasilitasi pembelajaran dan meningkatkan kinerja dengan cara menciptakan, menggunakan atau memanfaatkan dan mengelola proses dan sumbersumber teknologi yang tepat.

Pemanfaatan merupakan turunan kata dari kata "manfaat" yakni suatu penghadapan yang semata - mata menunjukan kegiatan menerima. Penghadapan tersebut pada umumnya mengarah pada perolehan atau pemakaian yang hal - hal yang berguna baik di pergunakan secara langsung maupun tidak langsung agar dapat bermanfaat. Sedang menurut Badudu (2001) pemanfaatan adalah hal, cara, hasil kerja dalam memanfaatkan sesuatu yang berguna.

Jika dikaitkan dengan masalah penelitian ini, maka pemanfaatan disini berarti menggunakan atau memakai suatu hal yang berguna yang dalam membantu proses pembelajaran dengan menggunakan atau memakai media berbasis komputer sebagai media dalam penyampaian informasi kepada publiknya yakni siswa SMP Negeri 21 Kerinci dimana peneliti memanfaatkan aplikasi power point sebagai media dalam menyampaikan materi pembelajaran Bahasa Inggris.

\section{Pengertian Media Pembelajaran}




\section{Jeni Tri Alida}

Kata media berasal dari bahasa latin medius yang secarah harfiah berarti 'perantara' atau 'pengantar'. Media merupakan perantara atau pengantar pesan dari si pengirim (Source) kepada si penerima (receiver). Media pembelajaran adalah media yang didesain secara khusus dan terstruktur guna merangsang pikiran, perasaan, perhatian dan minat peserta didik sehingga terjadi suatu proses pembelajaran (Warsita, 2008). Dalam proses pembelajaran media adalah segala sesuatu yang dapat di gunakan untuk menyalurkan pesan (bahan pembelajaran, sehingga dapat merangsang perhatian, minat, pikiran dan perasaan siswa dalam kegiatan belajar mengajar untuk mencapai tujuan pembelajaran.

Sardiman (2012) menyatakan bahwa pembelajaran adalah proses komunikasi, yaitu proses penyampaian pesan dari sumber pesan ke penerima pesan melalui media tertentu. Oleh karenanya komunikasi harus diciptakan dan diwujudkan melalui kegiatan penyampaian pesan dari setiap pengajar kepada pembelajar atau sebaliknya.

Dari pendapat diatas dapat disimpulkan bahwa media pembelajaran adalah sarana komunikasi yang dipakai untuk menyampaikan pesan dalam kegiatan belajar untuk mencapai tujuan pembelajaran yang akan di capai. Penggunaan media dalam proses pembelajaran juga harus disesuaikan, maka dari itu pengajar harus dapat memilih media pembelajaran yang baik untuk digunakan saat mengajar. Media pembelajaran yang baik haruslah sesuai dengan materi pembelajaran, mudah dalam proses penggunaannya serta media tersebut harus menarik bagi peserta didik sehingga proses pembelajaran dapat terlaksana secara optimal.

Berdasarkan uraian diatas dapat ditarik kesimpulan bahwa terdapat beberapa manfaat dari penggunaan media pembelajaran didalam proses belajar mengajar yaitu media dapat memperjelas penyajian pesan dan informasi, dapat meningkatkan dan mengarahkan perhatian siswa sehingga dapat menimbulkan motivasi dan minat belajar siswa, mengatasi keterbatasanketerbatasan yang di alami siswa.

\section{Media Pembelajaran Berbasis Komputer}

Pembelajaran berbasis Komputer adalah pembelajaran yang menggunakan computer sebagai alat bantu. Menurut Wena (2009: p.202), dengan pembelajaran berbasis komputer peserta didik akan berinteraksi dan berhadapan secara langsung dengan komputer secara individual sehingga apa yang dialami oleh seorang peserta didik akan berbeda dengan apa yang dialami oleh peserta didik lain. Salah satu ciri yang paling menarik dari pembelajaran berbasis komputer terletak pada kemampuan berinteraksi secara langsung dengan peserta didik. 
Media pembelajaran berbasis komputer yang popular saat ini dikalangan pendidik salah satunya adalah microsoft Power Point. Dimana aplikasi berbentuk tayangan berupa slide-slide yang dapat di atur sedemikian rupa sehingga dapat menarik perhatian siswa dengan menambahkan beberapa animasi-asnimasi yang menarik.

\section{Microsoft Power Point}

Menurut Daryanto (2010: p.163) power point adalah sebuah software yang dibuat dan dikembangkan oleh perusahaan Microsoft, dan merupakan salah satu program berbasis multimedia. Dalam komputer biasanya program ini dikelompokkan dalam program Microsoft Office. Definisi lain menurut Sianipar (2008: p.4), power point adalah suatu software yang digunakan dalam menyusun sebuah presentasi yang efektif, profesional, dan juga mudah. Microsoft powerpoint akan membuat sebuah gagasan menjadi lebih menarik dan jelas tujuannya jika dipresentasikan, karena microsoft akan membantu dalam pembuatan slide yang dinamis, termasuk clip art yang menarik, yang semuanya itu mudah ditampilkan di layar monitor komputer.

Perbedaan antara media presentasi dengan media pada umumnya adalah pada media presentasi pesan atau materi yang akan disampaikan dikemas dalam sebuah program komputer dan disajikan melalui perangkat presentasi berupa proyektor untuk menampilkan pesan atau materi berupa teks, gambar, animasi, maupun video yang dikombinasi secara utuh. Apabila dalam tampilan power point akan ditambahkan efek suara, maka diperlukan alat tambahan berupa speaker. Jadi, media power point adalah salah satu sarana penyampaian informasi dalam proses pembelajaran berupa program komputer yang dirancang untuk menyampaikan materi berupa slide dengan berbagai kemampuan pengolahan teks, warna, suara, video, gambar, serta animasi-animasi yang bisa diolah sendiri sesuai kreativitas penggunanya, yang kesemuanya dapat ditampilkan melalui perangkat presentasi berupa proyektor dan speaker.

Menurut Daryanto (2010: p.164), power point memiliki kelebihan sebagai berikut:

a. Penyajiannya menarik karena ada permainan warna, huruf, animasi, baik animasi teks maupun animasi gambar atau foto.

b. Lebih merangsang anak untuk mengetahui lebih jauh informasi tentang bahan ajar yang tersaji.

c. Pesan informasi secara visual akan mudah dipahami oleh siswa.

d. Guru tidak perlu banyak menerangkan bahan ajar yang sudahdisajikan. 


\section{Jeni Tri Alida}

e. Dapat diperbanyak sesuai kebutuhan dan dapat dipakai secaraberulang.

f. Dapat disimpan dalam bentuk data optik atau magnetik (CD, disket, flashdisk), sehingga praktis untuk dibawa kemana-mana.

Melihat beberapa kelebihan yang ada dalam media power point, maka pendidik hendaknya dapat memilih dan mempertimbangkan media power point sebagai media alternatif yang dapat digunakan dalam menyampaikan materi pelajaran, sehingga tujuan pembelajaran dapat tercapai secara optimal. Serta dapat mengkonversi presentasi dari Microsoft power point dalam mengembangkan konten Multimedia Pembelajaran Interaktif.

\section{Hakikat Minat Belajar}

Setiap individu mempunyai kecenderungan fundamental untuk berhubungan dengan sesuatu yang berada dalam lingkungan. Apabila sesuatu itu memberikan kesenangan kepada dirinya, kemudian ia akan berminat terhadap sesuatu itu. Minat timbul apabila individu tertarik kepada sesuatu, karena sesuai dengan kebutuhannya atau merasakan bahwa sesuatu yang akan dipelajari dirasakan berarti bagi dirinya dan ia pun akan berniat untuk mempelajarinya.

Secara bahasa, minat berarti perasaan yang menyatakan bahwa satu aktivitas, pelajaran atau objek itu berharga atau berarti bagi individu (2004: 255). Sedangkan menurut istilah, di bawah ini peneliti mengemukan beberapa pendapat ahli mengenai pengertian minat di atas, Menurut Ahmadi (2009:148) minat adalah sikap jiwa seseorang termasuk ketiga fungsi jiwanya (kognisi, konasi, dan emosi), yang tertuju pada sesuatu dan dalam hubungan itu unsur perasaan yang kuat.

Menurut psikologi, minat (interest) merupakan kecenderungan untuk selalu memperhatikan dan mengingat sesuatu secara terus menerus dan erat kaitannya dengan perasaan terutama perasaan senang, karena itu dapat dikatakan minat itu terjadi karena sikap senang kepada sesuatu. Orang yang berminat kepada sesuatu berarti sikapnya senang kepada sesuatu itu.

Minat merupakan gambaran sifat dan ingin memiliki kecenderungan tertentu. Minat juga diartikan suatu moment dari kecenderungan yang terarah secara intensif pada suatu tujuan atau objek yang dianggap penting. Objek yang menarik perhatian dapat membentuk minat karena adanya dorongan dan kecenderungan untuk mengetahui, memperoleh atau menggali dan mencapainya. 
Jadi, dari beberapa teori di atas, minat itu muncul akibat adanya kecenderungan untuk mengingat terhadap sesuatu secara terus menerus. Minat pun berkaitan erat dengan adanya perasaan senang terhadap sesuatu. Oleh karena itu, jika seseorang mempunyai perasaan senang terhadap sesuatu maka seseorang tersebut akan mempunyai minat untuk memperoleh sesuatu itu dengan usahanya agar keinginannya dapat tercapai.

\section{Hakikat Belajar}

Belajar secara etimologis, belajar memiliki arti "berusaha memperoleh kepandaian atau ilmu" (Baharudin \& Esa: 2007). Usaha untuk mencapai kepandaian dan ilmu tersebut merupakan usaha manusia untuk memenuhi kebutuhannya mendapatkan ilimu atau kepandaian yang belum dipunyai sebelumnya. Sehingga, dengan belajar manusia menjadi tahu, memahami, mengerti, dapat melaksanakan dan memiliki tentang sesuatu.

Belajar secara sederhana dikatakan sebagi proses perubahan belum mampu menjadi sudah mamapu, terjadi dalam jangka waktu tertentu. Perubahan yang terjadi itu harus secara relative bersifat mentap (permanen) dan tidak hanya terjadi pada perilaku yang saat ini Nampak (immediate behavior) tetapi juga pada perilaku yang mungkin terjadi di masa mendatang (pitensia behavior). Hal ini yang perlu diperhatikan ialah bahwa perubahanperubahan tersebut terjadi karena pengalaman (Irwanto :2003).

Crobach berpendapat bahwa learning is shown by change in behavior as a result of experience. Belajar sebagai suatu aktivitas yang ditunjukkan oleh perubahan tingkah laku sebagai hasil dari pengalaman. Howard mengatakan bahwa learning is the process by which behavior (in the broader sense) is originated or changed through practice or training. Belajar adalah proses dimana tingkah laku (dalam arti luas) ditimbulkan atau diubah melalui pratek atau latihan.

Berdasarkan pendapat para ahli di atas, maka dapat disimpulkan bahwa belajar adalah serangkaian kegiatan jiwa raga untuk memperoleh suatu perubahan tingkah laku sebagai hasil dari pengalaman individu dalam interaksi dengan lingkungannya yang menyangkut kognitif afektif, dan psikomotor (Bahri: 2008).

Menurut Hilgrad \& Bower dalam Purwanto (2003) belajar berhubungan dengan perubahan tingkah laku seseorang terhadap situasi tertentu yang disesbabkan oleh pengalamannya yang berulang- ulang dalam situasi tertentu itu, di mana perubahan tingkah laku itu tidak dapat dijelaskan atau dasar kecenderungan respon pembawaan, kematangan 


\section{Jeni Tri Alida}

atau keadaan sesaat seseorang (misalnya kelelahan, pengaruh obat, dan sebagainya).

Perubahan ini tidak terjadi karena adanya warisan genetik atau respon secara alamiah, kedewasaan, atau keadaan organisasi yang bersifat temporer, seperti kelelahan, pengaruh obat-obatan, rasa takut, dan sebagainya. Melainkan perubahan dalam pemahaman, perilaku, persepsi, motivasi, atau gabungan dari semuanya. Dan dalam belajar yang terpenting adalah proses bukan hasil yang diperolehnya. Artinya, belajar harus diperoleh dengan usaha sendiri adapun dengan orang lain itu hanya sebagai perantara atau penunjang dalam kegiatan belajar agar belajar itu dapat berhasil dengan baik.

Menurut definisi beberapa tokoh di atas, maka dapat disimpulkan pengertian belajar adalah proses usaha yang dilakukan oleh seseorang untuk memperoleh suatu perubahan tingkah laku yang baru secara keseluruhan sebagai hasil pengalamannya sendiri dalam interaksi dengan lingkungannya.

\section{Metode Penelitian}

\section{Setting Penelitian}

Penelitian ini di lakukan di salah satu sekolah menengah negeri di kecamatan air hangat timur kabupaten kerinci, yaitu SMP N 21 Kerinci. Penelitian ini di lakukakan untuk meningkatkan minat dan hasil belajar siswa pada mata pelajaran bahasa inggris dengan materi recount text di kelas VIII pada semester genap tahun ajaran 2019/2020 dengan memanfaatkan atau menggunakan media pembelajaran power point. Penelitian ini di maksudkan untuk melihat peningkatan minat dan hasil belajar siwa pada mata pelajaran bahasa Inggris setelah di manfaatkannya media pembelajaran dalam proses belajar.

\section{Karakteristik Subjek Penelitian}

Penelitian ini di laksanakan di kelas VIII di SMP N 21 Kerinci pada mata pelajaran bahasa inggris dengan materi reading skill. Subjek penelitian ini adalah siswa kelas VIII yang berjumlah 22 orang. Dalam pelaksanaan penelitian ini, peneliti di bantu oleh guru mata pelajaran bahasa Inggris yaitu Eni Marlina sebagai kolaborator atau observer.

\section{Variabel yang diselidiki}

Hal yang diberi tindakan pada kegiatan ini adalah memecahkan masalah pembelajaran di kelas VIII di SMP N 21 Kerinci pada mata pelajaran bahasa Inggris tahun pelajaran 2019/2020

\section{Rencana Tindakan}

Penelitian ini terdiri dari beberapa siklus, yang mana apabila rangkaian siklus I pembelajaran telah selesai dimana diketahui beberapa informasi dari hasil analisis data penelitian 
dan kemudian dilakukan refleksi guna membuat atau merancang pembelajaran yang lebih baik, maka di lakukan siklus II dengan tujuan untuk memperbaiki kekurangan atau kelemahan pada siklus sebelumnya yaitu siklus I sekaligus untuk meningkatkan kualitas pembelajaran. Apabila minat belajar siswa dari siklus I ke siklus II sudah menunjukkan peningkatan yang signifikan maka penelitian cukup dilakukan hingga siklus II. Namun jika minat belajar siswa belum menunjukkan adanya peningkatan yang signifikan, maka akan di lakukan refleksi guna membuat rancangan pembelajaran yanjg lebih baik untuk memperbaiki beberapa kelemahan yang terdapat pada siklis I dan siklus II.

\section{Teknik Pengumpulan Data}

Data pada penelitian ini dikumpulkan melalui pengamatan, angket, dan wawancara. Angket dalam penelitian ini digunakan untuk mengukur minat belajar siswa pada pembelajaran Bahasa Inggris dan diisi oleh siswa. Pada penelitian ini, angket diberikan kepada siswa sebanyak dua kali yaitu pra siklus dan setelah pelaksanaan tindakan disetiap siklus.Observasi pada penelitian ini dilakukan oleh peneliti untuk melakukan pengamatan terhadap penggunaan media power point oleh guru terhadap minat belajar siswa. Wawancara dalam penelitian ini digunakan untuk mengetahui respon siswa terhadap kegiatan belajar mengajar yang dilakukan oleh guru.

Analisis data pada penelitian ini dilakukan secara deskriptif, baik deskriptif kualitatif maupun deskriptif kuantitatif. Data yang dianalisis secara deskriptif kualitatif berupa lembar observasi untuk guru dan hasil wawancara, sedangkan data yang dianalisis secara kuantitatif berupa angket untuk mengukur minat belajar siswa dan lembar observasi minat belajar siswa. Angket minat belajar setiap siswa dihitung melalui tahapan berikut:

1. Menghitung skor angket minat belajar setiap siswa di setiap pertemuanRumus yang digunakan untuk mencari rerata skor minat belajar dan lembar observasi minat belajar diadaptasi dari buku Anas Sudijono (2011: p.81) dengan menjumlahkan data perolehan angket minat belajar dan lembar observasi minat belajar setiap siswa dibagi dengan jumlah data, maka didapatkan rumus berikut ini: 


\section{Jeni Tri Alida}

$$
\text { MBS }=\frac{A M B+L M B}{2}
$$

Keterangan:

$\mathrm{MBS}=$ Minat Belajar Siswa

$\mathrm{AMB}=$ Skor perolehan angket minat belajar siswa

$\mathrm{LMB}=$ Skor perolehan lembar observasi minat belajar siswa

2. Mencari rerata minat belajar siswa diakhir siklus Rumus yang digunakan untuk mencari rerata minat belajar siswa diakhir siklus diadaptasi dari Anas Sudijono (2011: 81) dengan menjumlahkan data skor perolehan minat belajar siswa di setiap pertemuan pada setiap siklus dibagi dengan jumlah data.

3. Kriteria Minat Belajar Siswa

Tabel: Minat Belajar Siswa

\begin{tabular}{ccl}
\hline No & Rentang & Kategori \\
\hline 1 & $35.00-$ & Tinggi \\
& 45.00 & \\
2 & $26.00-$ & Cukup \\
& 34.00 & \\
3 & $15.00-$ & Rendah \\
& 25.00 & \\
\hline
\end{tabular}

\section{Indikator Kinerja}

Indikator keberhasilan dalam penelitian ini adalah $80 \%$ siswa kelas VIII memperoleh skor minat belajar dalam kriteria tinggi dengan batas minimal skor minat belajar sebesar 36 disetiap siklusnya.

\section{Hasil Dan Pembahasan}

Pra siklus dalam penelitian ini dilaksanakan pada tanggal 16 Maret 2020. Untuk mengetahui skor awal minat belajar siswa kelas VIII, peneliti melakukan pengamatan terhadap siswa ketika kegiatan belajar mengajar berlangsung. Berdasarkan hasil observasi, ketika guru menjelaskan materi pelajaran kebanyakan siswa bermain sendiri. Ada siswa yang bermain dengan alat tulisnya, ada pula siswa yang bermain dengan teman sebangkunya. Selain itu, fokus siswa saat kegiatan belajar mengajar berlangsung hanya sebentar. Hal tersebut dikarenakan guru 
yang cenderung mendominasi kegiatan belajar mengajar. Selain melakukan pengamatan, peneliti juga memberikan angket minat belajar kepada siswa. Hal tersebut bertujuan untuk mengetahui skor minat belajar siswa. Adapun skor perolehan hasil pengamatan dan angket minat belajar siswa kelas VIII rata-rata minat belajar siswa ketika pra siklus menunjukkan angka 22,8 dimana dalam pengkategorian minat belajar termasuk dalam kategori rendah.

Setelah hasil angket dan observasi pra siklus di analisis dan di ketahui bahwa minat belajar siswa berada di kategori rendah, maka peneliti melaksanakan Langkah selanjutnya yaitu melaksanakan pembelajaran dengan menggunakan media power point sesuai dengan prosedur yang telah di rencanakan.

\section{Siklus 1}

Berdasarkan hasil evaluasi dari kegiatan observasi sebelum penelitian, maka untuk meningkatkan minat belajar Bahasa Inggris perlu adanya perencanaan yang terkoordinasi. Perencanaan dilakukan oleh peneliti bersama guru Bahasa Inggris kelas VIII. Adapun kegiatan yang dilakukan pada tahap perencanaan adalah sebagai berikut:

a) Peneliti dan guru Bahasa inggris menetapkan waktu pelaksanaan penelitian tindakan kelas. Penelitian dilaksanakan setiap hari Senin sesuai dengan jadwal mata pelajaran Bahasa Inggris kelas VIII SMP Negeri 21 Kerinci.

b) Menyusun Rencana Pelaksanaan Pembelajaran (RPP) Siklus I dilaksanakan dalam dua kali pertemuan. Adapun cakupan Rencana Pelaksanaan Pembelajaran (RPP) adalah terdiri dari identitas sekolah, mata pelajaran, kelas/semester, materi pokok, alokasi waktu, standar kompetensi dasar, kompetensi inti, tujuan pembelajaran, materi pelajaran, metode pembelajaran, media belajar, rincian kegiatan yang dimulai dari pendahuluan dan kegiatan inti serta kegiatan penutup.

c) Menetapkan materi yang akan di ajarkan di kelas

d) Menyiapkan dan membuat power point sesuai dengan materi yang akan disampaikan dengan judul "recount text". Dalam penggunaan media power point, pendidik berusaha menerapkan prinsip-prinsip kesederhanaan, keterpaduan, penekanan, dan keseimbangan.

e) Menyusun dan menyiapkan lembar observasi untuk mengetahui minat belajar siswa selama proses pembelajaran berlangsung. Lembar ini digunakan sebagai pedoman peneliti dalam mengobservasi kelas. 


\section{Jeni Tri Alida}

f) Mempersiapkan alat dan media yang akan digunakan untuk proses pembelajaran. Dalam hal ini mempersiapkan laptop, LCD projector, sebagai alat yang mendukung penggunaan media power point dalam pembelajaran.

Pelaksanaan tindakan siklus I adalah peneliti mengkondisikan siswa agar siap mengikuti pembelajaran. Peneliti menyampaikan tujuan pembelajaran. Guru memberikan kesempatan siswa untuk menanyakan hal-hal yang belum di mengerti terkait tujuan pembelajaran.

Setelah melakukan kegiatan awal, maka guru menjelaskan materi yang akan di pelajari pada siklus 1 ini, yaitu tentang recount text secara umum/garis besar. Pada Kegiatan ini guru menjelaskan materi, mengenai pengertian serta fungsi sosial dari teks recount dengan menayangkan slide berupa materi yang sedang di jelaskan tersebut. Setelah menjelaskan secara umum mengenai recount text maka selanjutnya guru membagi siswa dalam beberapa kelompok dimana setiap kelompoknya terdiri dari 4 hingga 5 orang, selanjutnya guru menginstruksikan kepada siswa untuk bergabung sesuai dengan anggota kelompoknya masing.

Setelah siswa duduk menurut kelompok masing-masing guru kemudian memastikan bahwa jika kondisi didalam kelas sudah kondusif maka guru bisa melanjutkan memberikan tugas yang harus di kerjakan secara Bersama-sama tiap kelompok. Guru menjelaskan apa saja tugas yang harus di lakukan oleh siswa, yaitu guru memberikan satu teks recount kepada setiap masing-masing kelompok yang harus didiskusikan secara Bersama-sama dengan anggota kelompoknya, kemudian siswa diminta untuk mengidentifikasi apa saja ciri-ciri, struktur kebahasaan serta fungsi social dari recount text.

Kegiatan diskusi kelompok diberikan waktu 40 menit, setiap siswa tuntut untuk aktif selama diskusi dengan menyampaikan ide-ide. Guru juga membantu siswa yang mengalami kesulitan selama membuat tugas dan selama proses diskusi berlangsung dengan cara menanyakan apakah siswa masih ada yang kurang jelas mengenai tugas yang di berikan. Guru dan observer tetap mengamati diskusi setiap kelompok dan membimbing mereka.

Untuk mengetahui bagaimana tentang pemahaman siswa tentang materi yang telah di paparkan, guru meminta kepada siswa untuk mempresentasikan Kembali tugas masing-masing kelompok di depan kelas yang berupa text recount per kelompok secara bergiliran, kemudian bagi anggota kelas yang lain menyimak dan mendiskusikan Bersama mengenai hasil tugas kelompok yang telah di presentasikan. 
Hasil dari siklus I pertemuan pertama, terdapat kelompok yang belum memahami benar tentang materi recount text, sehingga pada saat pemberian penugasan oleh guru setiap kelompok secara keseluruhan mengalami kesulitan dalam menyelesaikan tugas yang diberikan kepada kelompoknya. Hal ini di buktikan dengan dari 5 kelompok yang di tugaskan guru untuk mempresentasikan kembali hasil diskusinya hanya beberapa kelompok saja yang mampu mempresentasikan tugas tersebut, dan dari hasil pengamatan yang dilakukan oleh observer terhadap aktivitas masing-masing siswa pada saat pembelajaran dan hasil angket yang disebarkan pada akhir pertemuan pertama di siklus pertama hasil angket minat belajar siswa menunjukkan bahwa selama proses pembelajaran di pertemuan pertama memang mengalami peningkatan setiap masing-masing siswa, namun jika di lihat dari rata-rata hasil observasi dan angket, minat siswa masih tergolong dalam minat yang rendah. Dimana nilai rata-rata berada pada angka 24,9.

Pada siklus pertama ini, peneliti juga melakukan wawancara dengan beberapa siswa setelah waktu belajar usai, tanggapan siswa terkait penggunaan media power point adalahawalnya siswa merasa antusias dalam mengikuti proses pembelajaran, namun hal itu tidak berlangsung lama karena siswa merasa cepat bosan. Hal ini dikarenakan oleh tampilan pada setiap slide dalam power point terlalu monoton dan tidak ada variasi. Dimana guru menggunakan latar belakang yang masih polos, serta kalimat-kalimat yang terdapat di setiap slide menggunakan huruf dengan ukuran yang kecil sehingga siswa mengalami kesulitan ketika membaca materi yang dipaparkan melalui media power point tersebut.

Berdasarkan hasil pembelajaran pada siklus 1 dengan menggunakan media power point pada pembelajaran Bahasa Inggris, di ketahui bahwa penggunaan media power point dalam proses pembelajaran belum menunjukkan hasil yang signifikan terhadap minat belajar siswa, hal ini dapat dilihat dari nilai rata-rata minat belajar siswa belum mencapai indicator keberhasilan yang telah dirumuskan oleh peneliti sehingga hal ini menjadi acuan bagi peneliti untuk memperbaiki proses pembelajaran di siklus ke dua dengan memperhatikan kekurangankekurangan yang terjadi di siklus dan pertemuan-pertemuan sebelumnya.

Berikut adalah rincian perbandingan skor minat belajar siswa pada pra siklus/sebelum adanya Tindakan dan setelah adanya tindakan pada siklus I.

Tabel: Siklus I

\begin{tabular}{llll}
\hline No & Nama & Skor & Keterangan
\end{tabular}


Jeni Tri Alida

\begin{tabular}{|c|c|c|c|c|}
\hline & & pra siklus & Siklus I & \\
\hline 1 & $\mathrm{AE}$ & 20,5 & 26,5 & Meningkat \\
\hline 2 & $\mathrm{AR}$ & 22 & 29,5 & Meningkat \\
\hline 3 & A & 21 & 26,75 & Meningkat \\
\hline 4 & GG & 23 & 26,5 & Meningkat \\
\hline 5 & $\mathrm{JN}$ & 22 & 27 & Meningkat \\
\hline 6 & LO & 23 & 30,25 & Meningkat \\
\hline 7 & MK & 22,5 & 26,75 & Meningkat \\
\hline 8 & $\mathrm{~N}$ & 23 & 26,75 & Meningkat \\
\hline 9 & NMY & 24 & 29,25 & Meningkat \\
\hline 10 & NAS & 22 & 26 & Meningkat \\
\hline 11 & RMP & 25 & 28,75 & Meningkat \\
\hline 12 & $\mathrm{R}$ & 22,5 & 25,25 & Meningkat \\
\hline 11 & S & 22 & 26,5 & Meningkat \\
\hline 12 & SC & 22 & 29,25 & Meningkat \\
\hline 15 & SS & 23 & 27,25 & Meningkat \\
\hline 16 & TS & 23,5 & 26,25 & Meningkat \\
\hline 17 & TI & 25 & 26,25 & Meningkat \\
\hline 18 & TFW & 22 & 26 & Meningkat \\
\hline 19 & WNR & 23,5 & 27 & Meningkat \\
\hline 20 & YDY & 22 & 27,5 & Meningkat \\
\hline 21 & YA & 23 & 27,25 & Meningkat \\
\hline 22 & $\mathrm{ZP}$ & 24,5 & 26,75 & Meningkat \\
\hline \multicolumn{2}{|c|}{ Jumlah } & \multicolumn{2}{|r|}{599,25} & \\
\hline \multicolumn{2}{|c|}{ Rata-Rata } & 22,7727 & 27,23864 & \\
\hline
\end{tabular}

Pada siklus I didapatkan hasil tanggapan siswa melalui wawancara yang dilakukan oleh peneliti setelah waktu pembelajaran selesai di siklus I dimana pada siswa masih merasa cepat bosan karena tampilan pada setiap slide power point yang di tampilkan oleh guru didepan kelas masih monoton, ukuran tulisan yang terlalu kecil denga isi kalimat yang panjang. Sehingga siswa tidak tertarik dan kurang antusias dalam mengikuti proses pembelajaran.

Adapun hasil refleksi dari siklus I adalah :

a. Beberapa siswa masih ada yang tidak focus selama kegiatan pembelajaran. Maka di rekomendasikan atau di anjurkan untuk menambahkan focus dalam pengawasan siswa.

b. Materi yang di tampilkan guru masih terasa monoton dengan hanya menampilkan 
c. tampilan slide dengan kalimat panjang sehingga kurang menarik. Maka di rekomendasikan untuk memperbaiki tampilan-tampilan pada power point dengan menambahkan beberapa efek animasi atau lainnya agar terlihat lebih menarik.

\section{Siklus II}

Perencanaan Tindakan pada siklus II ini di lakukan dengan sebaiknya dengan memperhatikan hal-hal yang sekiranya kurang pada saat tindakan siklus I. Langkah-langkah dalam pelaksanaannya siklus II sama dengan Langkah-langkah di siklus I. pelaksanaan tindakan Siklus II sama dengan siklus sebelumnya. Pada siklus ke II ini peneliti juga melakukan wawancara dengan siswa guna untuk mendapatkan informasi mengenai tanggapan siswa terhadapa pembelajaran yang telah di lakukan dengan menggunakan media power point. Dari hasil wawancara, di dapatkan hasil bahwa pada pertemuan ke dua yaitu siklus II sebagian siswa sudah merasa senang dan tertarik dalam mengikuti proses pembelajaran dengan menggunakan power point, sehingga tingkat partisipasi siswa pun ikut meningkat. Berdasarkan rata-rata dari siklus II pada pertemuan pertama ini sudah menunjukkan peningkatan yang signifikan, namun jika di hubungkan pada pengklasifikasi terhadap indicator keberhasilan masih menunjukkan pada kategori cukup dan belum mencapai target yang di inginkan oleh peneliti yaitu pada kategori tinggi dengan kriteria 80\% dengan skor minat yang diperoleh sebanyak 36 .

Refleksi di siklus II ini bertujan untuk melihat hasil dari refleksi siklus II. Diantaranya pelaksanaan dari hasil refleksi siklus I yaitu:

1) Adanya tugas individu yang di berikan guru kepada siswa, lalu siswa mulai mengerjakan tugas yang di berikan, kemudian setelah itu secara Bersama-sama melakukan pengecekan hasil dari setiap tugas yang telah di kerjakan.

2) Guru mulai menambah fokus pengawasan. Hal tersebut terlihat saat kegiatan belajar mengajar berlangsung khususnya waktu guru memaparkan materi,tidak terdapat lagi siswa yang tidak focus dalam memperhatikan penjelasan guru.

3) Ketika memaparkan materi, guru menampilkan setiap slide dengan media power point dimana slide-slide tersebut telah di buat dengan adanya penambahan-penambahan animasi dan sejenisnya agar slide tersebut terlihat lebih menarik sehingga siswa lebih antusias dalam memperhatikan pejelasan yang di berikan oleh guru.

Selain kendala pada siklus I sudah mulai teratasi sesuai dengan harapan yang direncanakan pada refleksi siklus I, dalam siklus II ini indikator keberhasilan dalam penelitian ini 


\section{Jeni Tri Alida}

juga sudah tercapai. Dimana target dari penelitian ini $80 \%$ siswa kelas VIII memperoleh skor minat belajar dalam kriteria tinggi dengan batas minimal skor minat belajar sebesar 36, namun dalam siklus II $80 \%$ siswa kelas VIII memperoleh skor minat belajar $\geq 36$. Selain sudah mencapai indikator keberhasilan, rata-rata minat belajar siswa kelas VIII mengalami peningkatan disetiap siklusnya. Adapun peningkatan rata-rata minat belajar tersebut dapat dilihat dalam tabel berikut ini:

Berikut adalah table perbandingan skor minat siswa dengan perbandingan skor minat pada pra siklus, siklus I dan siklus ke II.

Tabel: Siklus I dan Siklus II

\begin{tabular}{|c|c|c|c|c|}
\hline \multirow{2}{*}{ No } & \multirow{2}{*}{ Nama } & \multicolumn{3}{|c|}{ Skor } \\
\hline & & pra siklus & Siklus I & Siklus II \\
\hline 1 & $\mathbf{A E}$ & 20,5 & 36,5 & 36,5 \\
\hline 2 & $\mathbf{A R}$ & 22 & 37,5 & 38 \\
\hline 3 & A & 21 & 36,25 & 36,5 \\
\hline 4 & GG & 23 & 31,5 & 31,5 \\
\hline 5 & $\mathbf{J N}$ & 22 & 32,5 & 32,5 \\
\hline 6 & LO & 23 & 36,5 & 37 \\
\hline 7 & MK & 22,5 & 35,75 & 36 \\
\hline 8 & $\mathbf{N}$ & 23 & 36 & 35,5 \\
\hline 9 & NMY & 24 & 37 & 37 \\
\hline 10 & NAS & 22 & 36 & 36 \\
\hline 11 & RMP & 25 & 36,5 & 32,5 \\
\hline 12 & $\mathbf{R}$ & 22,5 & 27,25 & 26 \\
\hline 11 & $\mathbf{S}$ & 22 & 31,5 & 31,5 \\
\hline 12 & SC & 22 & 37 & 37,5 \\
\hline 15 & SS & 23 & 29 & 29 \\
\hline 16 & TS & 23,5 & 37 & 38 \\
\hline 17 & TI & 25 & 37,5 & 38 \\
\hline 18 & TFW & 22 & 36 & 35,5 \\
\hline 19 & WNR & 23,5 & 36,5 & 37,5 \\
\hline 20 & YDY & 22 & 35,75 & 36 \\
\hline 21 & YA & 23 & 36,5 & 36,5 \\
\hline 22 & ZP & 24,5 & 36,5 & 36,5 \\
\hline & nlah & 501 & 599,25 & 772,5 \\
\hline & ta-Rata & 22,7727 & 27,23864 & 35,11363636 \\
\hline
\end{tabular}


Dari Tabel perbandingan di atas, dapat di lihat bahwa terdapat peningkatan minat siswa dimana minat siswa pada pra siklus atau sebelum di adakannya Tindakan berada pada nilai rata rata dengan kategori rendah yaitu 22,8. Setelah itu, di laksanakan Tindakan pada siklus I dengan hasil bahwa minat belajar siswa telah mengalami peningkatan hal ini dapat di lihat dari nilai ratarata yaitu dari 22,8 menjadi 27,23. Namun demikan, meskipun pada siklus I telah terjadi peningkatan minat belajar siswa, namun kategori minat siswa pada siklus I belum mencapai tingkat keberhasilan indicator yang telah di tetapkan peneliti dimana siswa dikatan berhasil apabila siswa medapatkan skor minat belajar siswa pada kategori tinggi dengan perolehan nilai minimal 36 dengan nilai rata-rata adalah 35,00.

Berdasarkan hal itu, maka di lakukan Tindakan pada siklus selanjutnya yaitu siklus II namun tetap memperhatikan perbaikan-perbaikan terhadap siklus I. Dimana hasil Tindakan dari siklus II ini, di dapatkan hasil bahwa siswa mengalami peningkatan minat belajar, dimana $80 \%$ atau sebanyak 17 siswa mendapatkan skor minat siswa dengan kategori tinggi. Hal itu berarti bahwa hasil yang di dapatkan pada siklus II telah mencapai indicator keberhasilan yag telah di tentukan.

Adapun peningkatan rata-rata minat belajar siswa dapat dilihat pada table berikut:

Tabel: Rata-Rata Minat Belajar Siswa

\begin{tabular}{cccc}
\hline No & Tindakan & Rata-Rata Minat Belajar & Kategori \\
\hline 1 & Pra Siklus & $\mathbf{2 2 , 8}$ & Rendah \\
2 & Siklus I & 27,23 & Cukup \\
3 & Siklus II & 35,11 & Tinggi \\
\hline
\end{tabular}

Berdasarkan dari tabel di atas terlihat dengan adanya pemanfaatan atau penggunaan media pembelajaran berbentuk power point dalam proses pembelajaran Bahasa Inggris di kelas sekolah menengah dapat meningkatkan minat belajar siswa.

Kesimpulan

Berdasarkan hasil penelitian tindakan kelas yang telah dilaksanakan dengan menggunakan media power point dapat meningkatkan minat belajar siswa pada mata pelajaran Bahasa Inggris kelas VIII SMP N 21 Kerinci telah mencapai indikator keberhasilan penelitian yaitu $80 \%$ siswa kelas VIII memperoleh skor minat belajar minimal sebesar 36. 


\section{Jeni Tri Alida}

Adapun saran berkenaan dengan penelitian ini adalah sebaiknya para guru dalam bidang studi Bahasa Inggris maupun bidang studi lainnya untuk dapat memanfaatkan media pembelajaran seperti power point dan sejenisnya agar proses pembelajaran tidak terasa monoton hanya bersumber dari guru saja dan bagi pemegang kebijakan di sekolah tersebut, agar mulai melibatkan penggunaan teknologi dalam proses pembelajaran, sehingga siswa memiliki gairah belajar yang tinggi.

\section{Daftar Rujukan}

Abror, Abd. Rachman.1993. Psikologi Pendidikan, Cet ke-4. Yogyakarta: PT Tiara Wacana Yogya.

Arikunto, S. 2010. Prosedur Penelitian Suatu Pendekatan Praktik. Yogyakarta: PT Rineka Cipta.

Daryanto. 2010. Media Pembelajaran Peranannya Sangat Penting dalam Mencapai Tujuan Pembelajaran. Yogyakarta: Gava Media.

Huda, Alamul. 2007. Seri Komputer Perkantoran Panduan Praktis Microsoft Power point 2007. Surabaya: Indah

Ilham, Risky. 2004. Belajar Sendiri Langsung Praktek Microsoft Power Point 2002. Surabaya: Indah.

Miarso, Yusuf Hadi. 2007. Menyemai Benih Teknologi Pendidikan. Jakarta: Kencana

Nurkarcana, Wayan, Sumartaman. 1986. Evaluasi Pendidikan, Cet ke-4. Surabaya: Usaha Nasional.

Pandapotan, Sianipar. 2008. Singkat Tepat Jelas Menggunakan Microsoft Office Power Point 2003. Jakarta: PT Elex Media Komputindo

Rusman, dkk. 2013. Pembelajaran Berbasis Teknologi Informasi dan Komunikasi. Jakarta: Raja Grafindo Persada.

Sabri, Alisuf.1996. Psikologi Pendidikan, Cet ke-2. Jakarta: Pedoman Ilmu Jaya.

Sardiman, S. Arif dkk. 2012. Media Pendidikan. Jakarta: Grafindo Persada

Singer, Kurt. 1987. Membina Hasrat Belajar di Sekolah Terjemah: Bergman Sitorus, Bandung: CV Remadja Karya.

Santoso, Subhan Adi, 2020. Media Pembelajaran Pendidikan Agama Islam Era Industri 4.0. Yogyakarta: Deepublish

78 Volume 7 No. 1, 1 Maret 2021 
Slameto.2002. Belajar dan Faktor-Faktor yang Mempengaruhinya, Cet ke-4. Jakarta: PT Rineka Cipta.

Soekarno dan Winataputra dalam Baharuddin dan Nur Wahyuni. 2002. Teori Belajar dan Pembelajaran. Yogyakarta: Global Pustaka Ilmu.

Sudijono, Anas. 2011. Pengantar Statistik Pendidikan. Jakarta: PT Raja Grafindo Persada.

Syah, Muhibbin. 2008. Psikologi Pendidikan dengan Pendekatan Baru. Bandung: Rosdakarya.

Tampubolon, D.P.1993. Mengembangkan Minat Membaca pada Anak. Bandung: Angkasa, Trianto. (2010). Panduan Lengkap Penelitian Tindakan Kelas (Classroom Action Research) Teori \& Praktik. Jakarta: Prestasi Pustaka Publisher.

Warsita, Bambang. 2008. Teknologi Pembelajaran Landasan dan Aplikasinya. Jakarta: Rineka Cipta.

Whiterington, H.C. 1978. Psikologi Pendidikan. Bandung: Aksara Baru.

Winkel W.S.1996. Psikologi Pengajaran. Jakarta: Gransindo.

Winkel, W.S. 2011. Psikologi Pengajaran. Salemba. Yogyakarta. 
Jeni Tri Alida

80 Volume 7 No. 1, 1 Maret 2021 